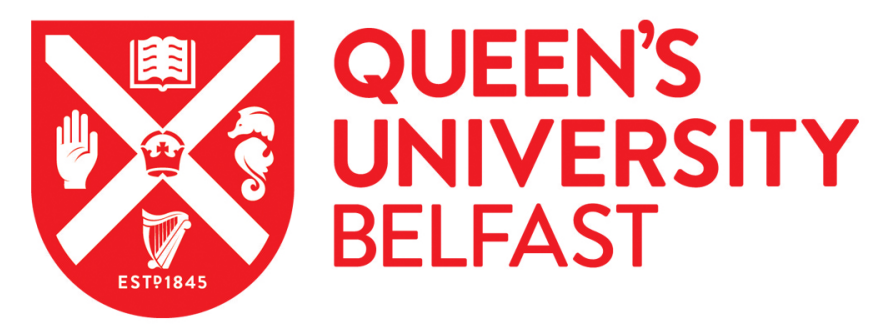

\title{
Majority voting as a catalyst of populism: preferential decision-making for an inclusive democracy
}

Pow, J. (2020). Majority voting as a catalyst of populism: preferential decision-making for an inclusive democracy: Book review. Irish Political Studies. https://doi.org/10.1080/07907184.2020.1749785

Published in:

Irish Political Studies

Document Version:

Peer reviewed version

Queen's University Belfast - Research Portal:

Link to publication record in Queen's University Belfast Research Portal

Publisher rights

Copyright ( 2020 Informa UK Limited trading as Taylr \& Francis.

This work is made available online in accordance with the publisher's policies. Please refer to any applicable terms of use of the publisher.

\section{General rights}

Copyright for the publications made accessible via the Queen's University Belfast Research Portal is retained by the author(s) and / or other copyright owners and it is a condition of accessing these publications that users recognise and abide by the legal requirements associated with these rights.

Take down policy

The Research Portal is Queen's institutional repository that provides access to Queen's research output. Every effort has been made to ensure that content in the Research Portal does not infringe any person's rights, or applicable UK laws. If you discover content in the Research Portal that you believe breaches copyright or violates any law, please contact openaccess@qub.ac.uk. 


\section{Book review for Irish Political Studies}

Majority Voting as a Catalyst of Populism: Preferential Decision-Making for an Inclusive Democracy, by Peter Emerson, Cham, Switzerland:

Springer, 2020, 227 pp., €77.99 (hardback), ISBN 978-3-030-20219-4

James Pow

Queen's University Belfast

Accepted manuscript

April 2020 
Across the globe, democracy is under strain - not necessarily because citizens are losing faith in democratic values, but because the performance of political systems often falls short of citizens' expectations (Norris, 2011). Against this backdrop, Peter Emerson embarks on a lively critique of one particular aspect of institutional design majority voting - which he links to the (sometimes) dangerous simplification of people's preferences and an unnecessarily restrictive form of democracy.

Building on his previous work (Emerson, 2007), Emerson argues that the greater use of preferential voting procedures, such as the Modified Borda Count (MBC), can help unlock a more substantive vision of democracy. The idea is that by giving people a full range of relevant options to consider, rather than forcing people to make binary choices, and by facilitating the expression of people's full range of preferences, rather than allowing people to express only a single preference, collective decision-making will be more inclusive and more accurate. To illustrate the limitations of majority voting and the potential for non-majoritarian alternatives to yield superior outcomes, the reader is taken on an intriguing journey exploring electoral and legislative decision-making across a range of cases in Europe and Asia.

Readers of this journal are likely to find the case study of Northern Ireland particularly relevant. Historically, it offers a compelling example of how majoritarianism can, in extreme circumstances, help to create the conditions for conflict to take hold. However, while Northern Ireland's contemporary political system promotes inclusive power-sharing, for the very purpose of avoiding the pitfalls of majoritarianism, Emerson observes that it still institutionalises majority voting. Beyond elections conducted using PR-STV, a voting system that is both proportional and preferential, decision-making within the Northern Ireland Assembly relies on the support of either a simple majority of legislators or parallel majorities of unionist and 
nationalist legislators. While Emerson highlights the potential for these arrangements to create gridlock, by giving each community an effective veto, more attention could be devoted to addressing why legislators from either group would be prepared to adopt preferential decision-making and lose their effective veto. In other words, even if we accept that reform is desirable, what incentives would make it likely?

A further paradox, arguably, lies in the principle of consent, the provision in the Good Friday Agreement to change Northern Ireland's constitutional status via concurrent referendums (in both Northern Ireland and the Republic of Ireland) using a simple majority rule. Here, an opportunity is lost to fully leverage this illustration by articulating why the debate on constitutional change is not one that can be easily reduced to binary options: remaining in the United Kingdom versus a united Ireland. Moreover, while the author sets out some of the limitations of a ' 50 percent plus one' decision rule, sceptical readers may be less convinced about the plausibility - and perceived legitimacy - of an alternative. This question should be of particular concern on matters of procedural design in a post-conflict polity.

Beyond the descriptive richness of individual case studies - filled with plenty of colour - there are two issues that restrict the overall contribution of this book. The first is theoretical. Readers seeking a systematic analysis of the relationship between majority voting and populism may be left searching for more. In spite of a sustained critique of majority voting, populism itself receives surprisingly little treatment. The lack of a clear definition of the concept from the outset inevitably makes it difficult to identify how majority voting accelerates populism - whether in the form of populist attitudes or support for populist parties - or, indeed, how preferential voting could slow it down. While it is true that the concept can be hard to pin down (see, for example, Mudde, 2007), it feels unsatisfactory to leave it as a catch-all term that 
encompasses a general set of problems facing democracy. This is a shame, as it leaves the book less equipped to engage with other relevant works, such as Norris and Inglehart's Cultural Backlash (2019), which finds that majoritarian electoral rules can serve as an obstacle to populist party seat gains, not a catalyst.

A final issue relates less to the substance of the argument, and more to the tone of the book - although the two are related. The reader will frequently encounter phrases such as 'For some old-fashioned reason ...' (p. 92) or 'For some ridiculous reason ...' (p. 93). The tone of exasperation that permeates the book - while no doubt genuine and reflecting the author's deep frustration with majority voting procedures results in some missed opportunities. By placing more emphasis on seeking to understand how such procedures have come about, and why they continue to exist, the argument in favour of reforming them would be both clearer and stronger. That said, it is still an argument worth considering. 


\section{References}

Emerson, P. (2007) Designing an all-inclusive democracy. Heidelberg: Springer.

Mudde, C. (2007). Populist radical right parties in Europe. Cambridge: Cambridge University Press.

Norris, P. (2011) Democratic Deficit: Critical Citizens Revisited. Cambridge: Cambridge University Press.

Norris, P. and Inglehart, R. (2019) Cultural Backlash: Trump, Brexit and Authoritarian Populism. Cambridge: Cambridge University Press. 